\title{
INTERNAL CREDIT RATING FRAMEWORK FOR REAL ASSET INVESTMENT
}

\author{
Deog Sang BAE (1D*,** \\ Risk Management Office, Hanwha Investment and Securities, Seoul, Korea
}

Received 27 March 2019; accepted 14 July 2019

\begin{abstract}
Real asset investment, which is assumed to be worthier than traditional assets in regards to exposure to income volatility, has become central to investment portfolios in financial institutions. However, the features of illiquidity and uniqueness involved in an individual real asset deal require private investors to review the full dimensions associated with the transaction structure. Banks and global credit rating agencies assess the quality of products by relying heavily on qualitative research executed by human insights and experiences. Such an approach ensures the comprehensiveness of the review process but it requires excessive resources in time and money. This study presents an internal rating system that instantly screens features of a deal proposal and provides a rating compatible with the global rating standard. The result shows that the outcomes created by this model are mostly clustered from BBB to BB. These findings match the average ratings for real assets, as determined by global rating agencies, which strengthens the practicality of the proposed model.
\end{abstract}

Keywords: credit rating, alternative investment, real estate, infrastructure, Bank for International Settlements (BIS).

\section{Introduction}

Investment positions in illiquid real assets, such as real estate and infrastructure, have been growing since the 2008 financial crisis (Choi, 2018). KPMG (2019) reported that more than $\$ 3$ trillion is annually invested for new infrastructure development around the world and predicted that the expenditure will double in meeting the United Nation's Millennial Development Goal. World Bank (2018) announced that in the half of 2018 , private capital of $\$ 43.5$ billion was invested in infrastructure greenfield projects. In terms of real estate, global transaction volume was $\$ 250$ billion in the third quarter of 2018, up 3.6\% from the beginning of the year and 1.2\% year-on-year (Barkham \& Luo, 2018).

Pension funds have facilitated capital construction projects by providing loans and equity while expecting to take stable cash flows in operation and a capital gain at the end. The study conducted by Heitmann and Davison (2018), where the degree of risk of unrated project finance loans is comparable to that of $\mathrm{BBB}$ grade corporate bonds when the project is at the stabilized time (usually the first three years) and comparable to that of A grade bonds after stabilization, bolsters interest in real assets. It argues that a high recovery rate of more than $80 \%$, even during economic turmoil, attracts investors' appetites. CBRE (2017), a global real estate consulting firm, reveals the empirical result that the yield trend of $\mathrm{BBB}$ shows a similar pattern in the capitalization rate of commercial real estate. $M \& G$ Institutional (2017) strengthens CBRE's argument by presenting a study that observes the stability of spread gap between these two products in the United Kingdom.

The inevitable feature of information asymmetry principally caused by an asset's heterogeneity negatively affects trading and liquidity (Peng \& Brucato, 2004; Raz, Shenhar, \& Dvir, 2002). Garmaise and Moskowitz (2003) suggested alternatives to alleviate uniqueness: interest for properties with stable cash flows and avoidance for professional brokers. However, these suggestions are not practically applicable to mega-projects that require high capital to buy neighboring properties and are managed by a single broker.

Most financial institutions adopt a procedural decision process to tackle issues mostly caused by information asymmetry: proposal review, risk department engagement, approval by the committee (Morgan Stanley, 2014). First, dealers review all dimensions of a proposed deal according to the regulatory guidelines and corporate investment policy. Second, the risk department assesses risks in-depth. During this process, the dealer and the inhouse risk assessor work together for due diligence. Lastly, the investment committee reviews the proposal and makes a final decision. This systemic approach helps clearly

\footnotetext{
${ }^{*}$ Corresponding author. E-mail: agentbae@gmail.com

** Civil Engineering Department, Chung Ang University, Seoul, South Korea

Copyright $\odot 2019$ The Author(s). Published by VGTU Press
}

This is an Open Access article distributed under the terms of the Creative Commons Attribution License (https://creativecommons.org/licenses/by/4.0/), which permits unrestricted use, distribution, and reproduction in any medium, provided the original author and source are credited. 
identify the outlook of a deal but requires excessive use of human capital and can lead to a bias in decision making.

Credit rating assessment is a plausible option but only selectively applicable. Credit ratings support the financial market in three ways: asset transparency, risk premium calculation, and simplicity of understanding. First, an asset rated by a global rating agency can attract financial institutions more easily than a nonrated asset, because the 3rd party examines the asset's performance and presents the result after in-depth analysis (Tang, 2009). Second, the financial industry determines the risk premium of the asset by using a credit rating because market participants agree the rating itself is a trusted source and an absolute proxy for default probability (Hull, Predescu, \& White, 2005; Longstaff, Mithal, \& Eric, 2005). Third, the simplicity of the rating system arranged in alphabetical order helps public investors intuitively grasp the risk profile (He, Wang, \& Wei, 2011). However, only $38 \%$ of the infrastructure and real estate deals from 1983 to 2014 related to project finance have been rated (Heitmann, Hawken, \& Davison, 2017; Meers \& Humphrey, 2017). Two attributes explain this: cost and time spent in the rating service and the possibility of having a lower grade than expected. In addition, the quality of the rating itself can be an issue (Bae \& Damnjanovic, 2018). Bonsall, Koharki, and Neamitu (2015) argued that an external environment not aligned with the asset itself, such as economic incentives, can damage reliability.

Such complexity in risk assessment has triggered development of a new risk assessment platform but the invention has faced challenges. Bank for International Settlements (BIS, 2017), after observing that a predeveloped framework that determines the quality of an asset by screening lending attributes both loan to value and internal rating is not fully fit to the BIS's regulatory standard of risk judgement, claimed that the current system should be reengineered. The internal rating referred here is the outcome derived by a financial institution's own rating system. In specific, United Nations Economic Commission for Europe Real Estate Market Advisory Group (UNECE REM, 2012) recommended applying a predeveloped rating model proposed by The European Group of Valuer's Associations (TEGoVA, 2003). TEGoVA invented a property rating method compatible with the requirement of Basel II. It, in order to ensure precise review and judgment of a target asset, developed a standalone methodology adaptable for each property category. Principle questionnaire categories, such as market, location, property, and cash flow, are the same regardless of asset class but sub assessment criteria vary. The total score is calculated by multiplication between the assigned score of each criterion and its weight.

In spite of its systemic guideline, tendency of financial institutions that tended to rely on both the LTV and the premature internal rating system as well as overlooked the lack of liquidity in the real estate market led to risk control failure in the 2008 financial turmoil. Specifically, the internal model is perceived as unqualified for credit assessment due to the variability of rating outcomes (BIS, 2017). It is expected that the forthcoming Basel IV will reinforce the policy of LTV and internal model development (McKinsey \& Company, 2017).

Developing an internal rating model specifically for real assets is unavoidable. The matter is how much an internal model functions for the perspective of accuracy and convenience enhancement. This study develops a model that achieves these two premises. This platform is not newly created but is created in a simplified course of currently available rating methodologies. As such, this study extracts key risk criteria by reviewing previous studies and suggests ideas for a systemic approach. Then, the validity of the new model is confirmed by an analysis of case studies, reflecting the needs of investment banks seeking a fast decision. This rating mechanism, which can funnel large amount of investment proposals to small candidates, reduces the consumption of resources for filtering, and finally, expedite the speed of the investment committee judgement.

\section{Applications and limitations of previous studies}

Both global rating agencies and academic researchers have studied the subject of internal ratings (Allison \& Tufts, 2015; Bae \& Damnjanovic, 2018; Korean Ministry of Land Infrastructure and Transport, 2016; Medina \& Marty, 2018; Morgan Stanley, 2014; Nikolića, Jednak, Benković, \& Poznanić, 2011; Piney, 2003; Renigier-Biłozor, Wisniewski, Kaklauskas, \& Biłozor, 2014; Ribeiro \& Ferreira, 2017; Standard \& Poor's, 2014). Taking into consideration relevance to this study and concreteness of information, six previous studies are selected: Bank for International Settlements (BIS, 2001); Moody's (Medina \& Marty, 2018); Standard \& Poor's (2014); Renigier-Biłozor et al. (2014); Failure Mode and Effect Analysis (FMEA) (Nikolića et al., 2011); and the Korean infrastructure guidelines (Korean Ministry of Land Infrastructure and Transport, 2016) (see Table 1).

Table 1. Critical variables

\begin{tabular}{|l|c|c|c|c|c|c|}
\hline \multicolumn{1}{|c|}{ Category } & BIS & Moody's & S\&P & $\begin{array}{c}\text { Renigier-Biłozor } \\
\text { et al. }\end{array}$ & FMEA & $\begin{array}{c}\text { Korean } \\
\text { guideline }\end{array}$ \\
\hline Revenue Capacity & $\sqrt{ }$ & $\sqrt{ }$ & $\sqrt{ }$ & & $\sqrt{ }$ & $\sqrt{ }$ \\
\hline Internal Capacity & $\sqrt{ }$ & $\sqrt{ }$ & $\sqrt{ }$ & & $\sqrt{ }$ & $\sqrt{ }$ \\
\hline Financial Leverage & $\sqrt{ }$ & $\sqrt{ }$ & $\sqrt{ }$ & & $\sqrt{ }$ \\
\hline Country Risk & $\sqrt{ }$ & $\sqrt{ }$ & & $\sqrt{ }$ & & \\
\hline Location & & & & & & $\sqrt{ }$ \\
\hline
\end{tabular}


BIS (2001) does not obligate installation of an internal model for specialized loans (a type of project finance loan for a real asset's greenfield project), but it strongly recommends institutions develop their own systems and provides an implementation guideline. It proposed an internal rating model that contains six criteria: financial strength/flexibility, collateral control, strength of management, other risk mitigation, project track record, and project phase. BIS expects this approach to contribute to the precise estimation of required capital exposure against project finance lending, in considering the environment that unidentified risk factors can significantly impact a bank's survivability. Similar to the BIS approach, Bank of England (2019) developed an internal ratings approach particularly for a residential mortgage. Its model results in an outcome by assessing the quality of seven attributes: financial strength, political and legal environment, transaction characteristics, construction risk, supply risk, sponsor's strength, and security package.

Second, a high standard employing a state-of-theart rating system strengthens the reliability of outcomes driven by Moody's (Medina \& Marty, 2018) and Standard \& Poor's (2014). These agencies' transparent sharing of helicopter views of their rating methodologies with the public helps promote the credibility of a rating outcome. Specifically, for project finance loans, an array of rating models in regards to asset type developed from a standalone methodology helps closely and comprehensively assess investment risks inherited from the heterogeneous nature of an individual real asset (Medina, 2018; Standard \& Poor's, 2014). However, the heavy involvement of qualitative analyses in all aspects except leverage and coverage criteria is a matter (Griffin \& Tang, 2012). A lack of uniformity in ratings due to raters' different conceptions of a project can cause quality problems (Fracassi, Petry, $\&$ Tate, 2013). In addition, a heavy expense in time and money caused by complexity in ratings impedes periodic updates. As such, an outdated rating potentially puts the investor's position in danger (Bae \& Damnjanovic, 2018; Morgenson, 2009).

Third, Renigier-Biłozor et al. (2014), who developed a hypothetical assessment model for capturing economic motivation between sellers and buyers, attempted to assess the regional market risks of residential investments in Poland. Unlike the rating models of Moody's and S\&P, this framework quantitatively operates while limiting its source to publicly accessible data. The lack of data availability weakens the practicality of this study.

Fourth, FMEA illustrates critical risks by utilizing a Risk Priority Number (RPN) that is the result of multiplying three factors: occurrence rating (Failure Frequency), detection rating (Failure detection likelihood), and security rating (Failure impact) (Moultrie, 2019). Segismundo and Miguel (2008) briefly summarized its history. In late 1940, the US Department of Defense applied FMEA in the field of gauging readiness and operation. Success on the part of the military encouraged NASA to use it for the Apollo program, and the automobile manufacturer
Ford also adopted the tool in 1970. Currently, it is one of the core quality control tools in the industry. Nikolića et al. (2011) applied FMEA to examine the financial risks of investing in the Serbian energy market. They defined risk categories according to a rule proposed by Yescombe (2002): commercial, financial, and political risks; and calculated risk on each criterion.

Last, the Korean government (Korean Ministry of Land Infrastructure and Transport, 2016) published a guide to overseas infrastructure development. The risk criteria included in the assessment matrix consist of four parts: sovereign risk, developer profile, business idea, and public contribution. The result of each part is produced by combining qualitative (20\%) and quantitative (80\%) subpart scores.

All studies except Renigier-Biłozor et al. (2014) suffer from the same problem of heavy resource consumption in qualitative research for assessment. However, considering the complexity of a real asset transaction, a numerically driven rating is not effective, either. This contradiction motivates this study.

\section{Rating architecture}

\subsection{Rating definition}

The rating scale (see Table 2) applied in this study is based on the global rating standard from AAA to C, but for simplicity, sub-rating indicators in grades such as positive, neutral, and negative are not included. AAA is the highest grade in the array, implying an extremely strong financial capacity to meet commitments. $\mathrm{C}$ is the lowest, implying high vulnerability to non-payment and low recovery rate at default. The financial industry categorizes grades from $\mathrm{AAA}$ to $\mathrm{BBB}$ as investment and those from $\mathrm{BB}$ to $\mathrm{C}$ as speculation.

\subsection{Rating process}

The rating model presented in this study is developed by referring to the Moody's project finance methodology (Moody's (Medina \& Marty, 2018)). The adoption strengthens the reliability of the new model in three ways. First, the fact that Moody's outcomes are globally recognized in the financial market validates the trustworthiness of its system. Bonsall, Koharki, and Neamtiu (2017) empirically found that a rating result vary in regards to applied rating methodology, depth of information asymmetry, and risk level of borrower credit status. Such finding reinforces the importance of appropriate application of rating architecture and strengthens the reliability of the credit rating agency's assessment platform. The development based from such a practical method strengthens the potential of the new model in terms of quality. Second, Moody's framework is simpler than S\&P's from the perspective of rating procedure and judgment criteria, which corresponds to the aim of this study to remove excessive assessor subjectivity. Lastly, Moody's shares the rating process and the weight of each evaluation criterion with 
Table 2. Rating definition

\begin{tabular}{|c|c|c|c|}
\hline Grade & Definition & Score & $\begin{array}{l}\text { Quality of } \\
\text { investment }\end{array}$ \\
\hline AAA & Extremely strong financial capacity to meet its obligations & 1 & \multirow{4}{*}{$\begin{array}{l}\text { Investment } \\
\text { grade }\end{array}$} \\
\hline AA & Very strong financial capacity and slightly differ from the credit quality of AAA equivalent & 3 & \\
\hline A & Susceptible to adverse economic conditions but strong financial capacity & 5 & \\
\hline $\mathrm{BBB}$ & $\begin{array}{l}\text { Adequate protection equipped against adverse economic condition but in some degree exposed } \\
\text { to a risk }\end{array}$ & 7 & \\
\hline BB & Facing major ongoing uncertainties and exposure to adverse conditions & 9 & \multirow{5}{*}{$\begin{array}{l}\text { Speculative } \\
\text { grade }\end{array}$} \\
\hline B & More vulnerable to default than BB but obligor has the financial capacity to meet its commitments & 11 & \\
\hline CCC & $\begin{array}{l}\text { Vulnerable to nonpayment and the financial capacity to payment solely depends on favorable } \\
\text { business conditions }\end{array}$ & 13 & \\
\hline CC & This grade is given when a default is expected to impend in the near future & 15 & \\
\hline $\mathrm{C}$ & Highly vulnerable to nonpayment. Low recovery expected at default & 17 & \\
\hline
\end{tabular}

Note: Definition: S\&P Global Ratings (2018). Score: Moody’s (Medina and Marty, 2018).

the public. The comprehensiveness of the BIS and S\&P methodologies are comparable to the Moody's but, unlike Moody's, they do not share such information. The information shared by Moody's provides guidelines that minimize the chances of an error in the development.

In particular, this study replicates two rating procedures, such as project rating and rating adjustment, from the Moody's framework but designs its own assessment attributes. For project rating, the Moody's assessment consists of business profile (50\%), operating risk (20\%), and leverage and coverage (30\%) (see Figure 1). Then, the rating is adjusted in consideration of liquidity, structural features, and etc. However, such complexity requires extensive resources in time and money. This study that aims for instant rating delivery substitutes each Moody's assessment element to an attribute that captures core characteristics of the element. For example, business profile in Moody's is substituted to demand, operating risk to operator and constructor, and leverage and coverage to loan to value, in the same weight, respectively. Figure 1 describes the connection between the Moody's framework, conceptual project cash flow, and this study's rating criteria. The left table illustrates major components of the Moody's system and their weights. The middle figure shows a general structure of cash flows of a project. The right figure identifies three components of the project rating architecture of a new system. The rating adjustment in the new model contains only two modifiers, such as

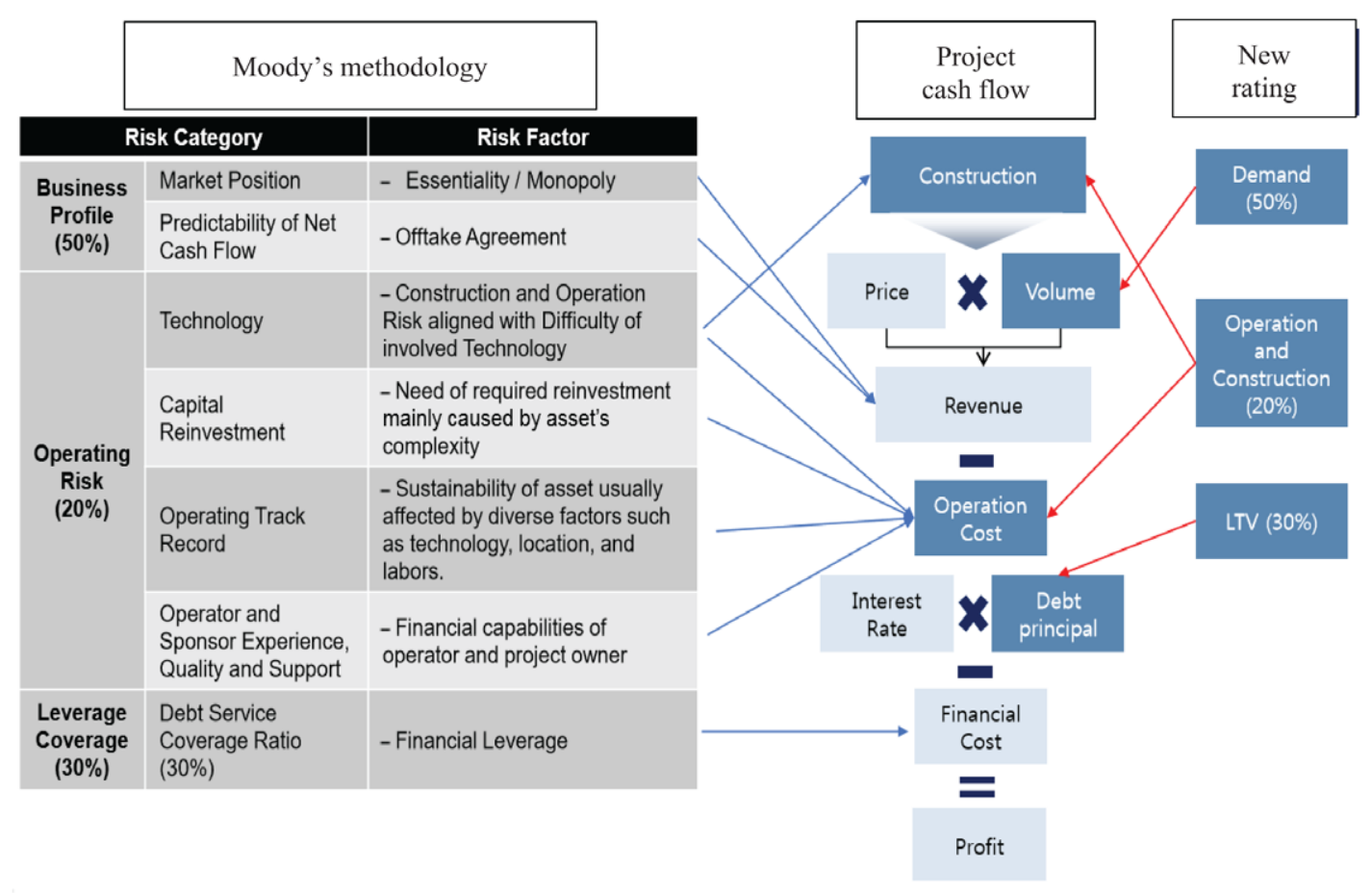

Figure 1. Moody's rating architecture 


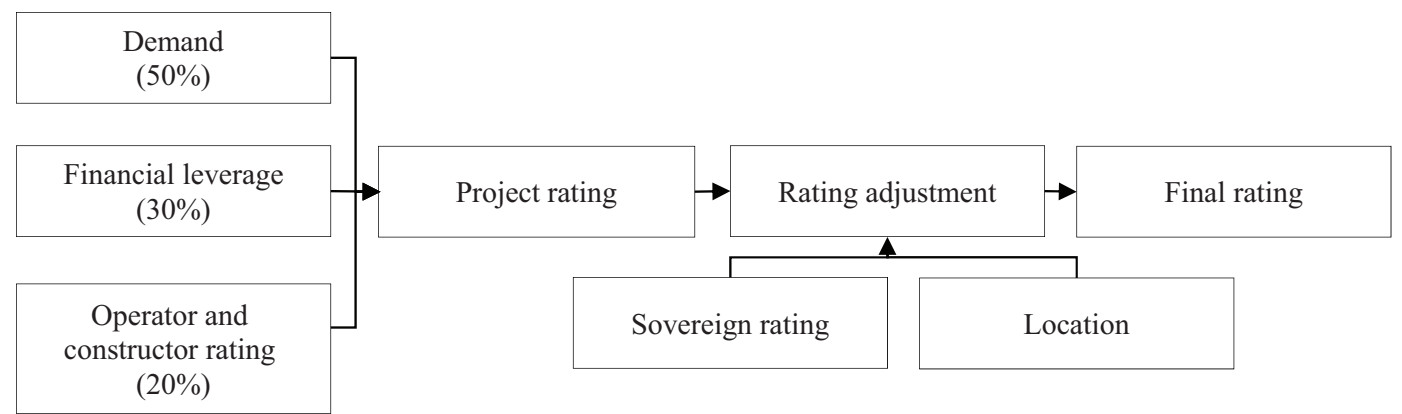

Figure 2. Rating process

location and sovereign rating, which is unlike Moody's approach that requires professional judgement in liquidity, structural protection, and etc. The backbone of the new rating model is presented in Figure 2. The rating process of each criterion is described in the following chapters.

\subsubsection{Demand}

The link between the business profile on the left and the revenue on the right implies that the Moody's feature is fit to the assessment of revenue capacity (see Figure 1). Here, this study decides to only cover the demand potential under the assumption of uncertainty in price control in the market. Illiquidity in the real asset market causes an unstandardized valuation regarding to characteristics of each property. Previous transaction record provides a proxy of the dollar per square meter unit price but does not ensure accuracy in pricing the target's asset value.

In particular, the rating process of the demand side (see Figure 3 ) is intuitively developed by summarizing the Moody's business profile rating criterion. It is rated by the combination between asset status and quality of offtake contract. Asset status is separated into brownfield and greenfield. A brownfield means an asset has already been constructed and fully being operated and generating a stable income; its main advantage is to reduce uncertainty involved in the planning and construction phases. On the other hand, a greenfield means a new construction project, requiring a huge capital investment for construction and possessing no historical performance records; this leads to an upshift in the investor's required return rate.

In the case of a brownfield project, the first task is to examine validity of an offtake contract. Here, the validity is ensured if two conditions are met such that the offtake contract is continuously effective and the remaining contract length is at least twice more than the asset holding period. A project with sufficient time remaining on an offtake contract to ensure economic benefits if the project delivers output as stipulated in the contract leads to less uncertainty for investors than a project with an impending offtake contract termination, all else being equal. This means that investment exit will presumably be safe if the period of the offtake contract is sufficient. The degree of sufficiency is linked to comfort at investment exit. A situation where the next buyer secures the same conditions on the offtake contract that the seller had been located cannot undercut the project value in terms of revenue capacity. The grade of a project, which meets all requirements above, is assumed of the offtaker's credit rating of being granted by a global rating agency. The development of such approach is influenced from the Moody's rating process of "predictability of net cash flow", which measures the certainty of product sales by reviewing the qualities of payment guarantee and credit quality of the payer if an offtake contract is established. Moody's rating ranges from AAA (monopoly and sole provider of essential services) to CC (perfect competition and weak market power).

In the case of invalid offtake contract, the asset's demand can be indirectly inferred by reviewing the market capacity. Measuring the capacity requires reliable sources, which can clearly articulate economic condition around the neighbouring area, such as transaction record, government statistics, and world-renowned firm (example: CBRE, JLL, and Savills)'s consulting reports. This approach sets to the rating's cap as of $\mathrm{BBB}$ in considering unambiguity in such process. The market assumes that the risk and return profile of real assets is comparable to $\mathrm{BBB}$ grade's corporate bond, which is the lowest grade in the investment rating group. If reliable sources are unavailable, a $\mathrm{C}$ grade is assigned.

Likewise, in the case of a greenfield project, the validity of an offtake contract is considered at most. If valid, the rating of an offtaker is assumed as of the demand quality of an asset. Otherwise, the market capacity is used as the source. It involves the highest risk in revenue capacity projection, leading to the adoption of the most conservative approach. In such, the rating's cap is set to $\mathrm{BB}$, which is one grade lower than the brownfield's max. Under the cap, the rating is assigned by selecting the lowest between the developer credit rating, the constructor credit rating, and the grade derived by market analysis mentioned above. Developer and constructor ratings are included because renowned parties that tend to minimize their reputation risks are highly likely to join projects they expect to be completed successfully. In addition, the $\mathrm{BB}$ cap, the highest grade in the speculative rating group, is introduced because those three conditions cannot directly mitigate the demand risk. If this method is not applicable, a $\mathrm{C}$ grade is assigned. 


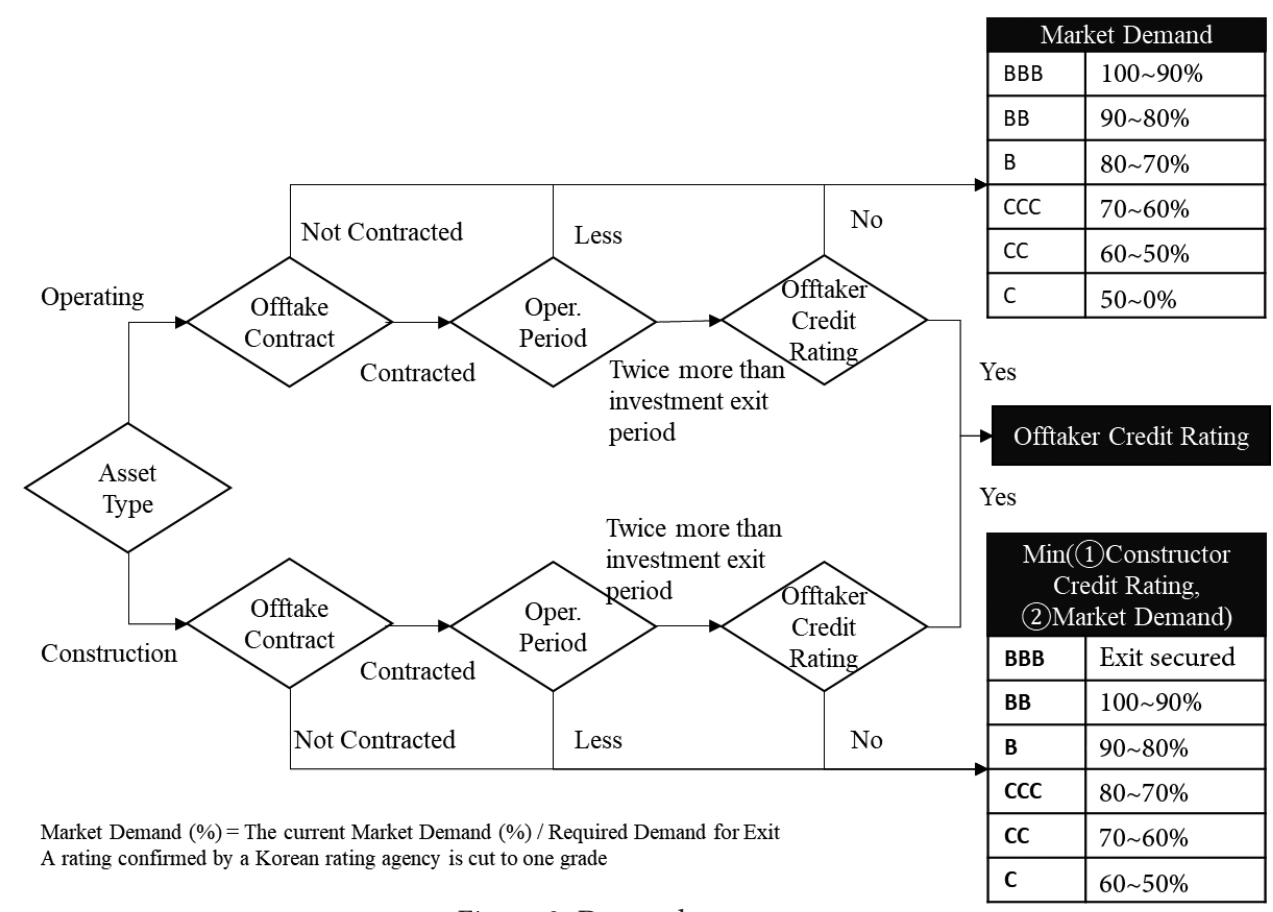

Figure 3. Demand assessment

\subsubsection{Constructor and operator}

Moody's assesses operator and constructor sides in professionally analysing four sub-factors: technology, capital reinvestment, operating track record, and operator and sponsor experience (see Figure 2). Of these, the first and second variables are critical, as they require more qualitative analysis than the others. Technology means complexity in construction and operation. Assets involving commercially proven and widely used technology, such as schools and apartments, are positioned as low risk, but assets involving highly advanced technology, such as nuclear power plants and chemical plants, are positioned as high risk. Moody's assigns AAA to commercially proven technology and CC to commercially unproven technology. The requirement for capital reinvestment is typically proportionate to the complexity of the technology involved. Here, AAA means there is no capital reinvestment exposure, and CC means capital reinvestment is required in amounts exceeding the project's value. FMEA and the Korean guidelines includes a similar array of risks.

The new rating also assesses these two parts, but for simplification, rates them by referencing to both parties' credit ratings confirmed by a global rating agency. This simplification is based on the fact that the strength of business partners is a critical key to achieving project goals. A willingness to maintain the reputation of a renowned building contractor motivates a firm to selectively bid on projects and to complete construction with full effort. This is also true of renowned enterprises that operate a complex asset. Table 3 illustrates the rating approach in regards to construction and operation phases. The construction phase means the period before the asset is fully operational and generates income as expected. The operation phase stretches from the termination of the construction phase to the asset's lifetime. As discussed, the construction company's credit profile, as rated by the global agency, represents the status of internal capacity in the construction phase. In the operation phase,

Table 3. Constructor and operator rating scale

\begin{tabular}{|c|c|c|c|c|c|c|c|c|c|c|}
\hline Category & Remark & \multicolumn{9}{|c|}{ This study's rating scale } \\
\hline $\begin{array}{l}\text { Const. } \\
\text { phase }\end{array}$ & $\begin{array}{l}\text { Constructor's } \\
\text { global rating } \\
\text { assumed }\end{array}$ & AAA & $\mathrm{AA}$ & A & $\mathrm{BBB}$ & $\mathrm{BB}$ & B & CCC & $\mathrm{CC}$ & $\mathrm{C}$ \\
\hline \multirow[t]{2}{*}{$\begin{array}{l}\text { Operator } \\
\text { phase }\end{array}$} & $\begin{array}{l}\text { Operator's } \\
\text { global rating } \\
\text { assumed }\end{array}$ & AAA & AA & A & $\mathrm{BBB}$ & $\mathrm{BB}$ & B & CCC & $\mathrm{CC}$ & $\mathrm{C}$ \\
\hline & $\begin{array}{l}\text { If rating } \\
\text { unavailable }\end{array}$ & - & - & - & $\begin{array}{c}\text { No critical } \\
\text { event } \\
\text { record }\end{array}$ & - & - & - & - & $\begin{array}{l}\text { Critical } \\
\text { event } \\
\text { record }\end{array}$ \\
\hline
\end{tabular}

Note: ※ A rating judged by a Korean rating agency is downshifted by one grade. 
the operator's rating is used, if available. Otherwise, BBB, the lowest grade in the investment group, is assigned if any accidents have been recorded since the start of the operation phase. In the case of a fatal event recorded since the start, then, the grade of $\mathrm{C}$ is assigned.

\subsubsection{LTV}

Net profit is determined after operating income is adjusted to account for financial expenses. A high debt ratio results in a loss in net profit and damages security on the debt, making this factor critical. Two of the BIS's categories, financial strength and collateral control, separately describe this feature, but they can be consolidated into one measurement of LTV (loan to value). Although the debt service payment is calculated by multiplying loan size and interest rate, the LTV only reflects the half. However, LTV is adaptable when there is limited usable information. Direct measurement of DSCR (Debt Service Coverage Ratio) requires a high level of accuracy about cash flow. In terms of collateral control, LTV is a useful indicator of how the level of tranche principally determines the security of a holding.

Moody's and S\&P both quantitatively judge the quality of financial status by using DSCR derived from the future cash-flow projection. These companies developed multiple sets of DSCR scales to use according to the characteristics of the target project. FMEA and the Korean guidelines do not directly review DSCR but do indirectly consider it because they contain analysis of net cash flow.

Instead, this study uses LTV as a representative indicator of financial leverage (Table 4). The typical source referred to is an acquisition plan, called Information Memorandum (IM), illustrating debt characteristics of volume, interest rate, and amortization plan. Basel III also defines that "loan to value" is a core risk factor in applying a standardized approach that assesses the credit risk of a residential mortgage (BIS, 2017). In particular, it assigns a risk weight according to the combination between the dependence of property cash flow and level of loan to value. Unlike global rating agencies, this study does not include sensitivity analysis encompassing a wide array of stressful scenarios because resolving complexity relies on the rater's subjective considerations.

\subsubsection{Country risk and location (adjustment)}

Table 5 presents the rating adjustment. In terms of country risk, BIS describes political upheaval, macroeconomic instability, and legal changes as sources of risk to the country that may critically downsize an asset's performance. S\&P, FMEA, and the Korean guidelines include sovereign risks in their assessment frameworks. In particular, S\&P has a modification process that allows upshifting of the predefined project rating by one notch, to as high as the local currency rating of the country, if the services and products delivered by the project are essential links to the economy and are not replaced by other assets in a short time. If not critically positioned, the adjustment can be triggered by reviewing the conditions of economic benefits. It bars the project rating up to the sovereign foreign currency credit rating, except in a few cases where projects surpass stress tests associated with currency transfer. This approach, however, limitedly reflects the tendency of a market player's risk appetite. The first consideration for foreign investment is to investigate a country's economic and political surroundings, as sovereign risks are uncontrollable in the market. The FMEA includes a nation's political risks, caused by policy instability and corruption. The Korean guidelines quantitatively assesses the risk, using the public data of GDP growth rate and international rank of political corruption.

Location is another key variable. BIS, in the "Supervisory Categories for Income-Producing Real estate," states that geographical location affects an asset's quality across a wide array of features: market conditions and future prospects; strength of management and property quality; and collateral control. In practice, S\&P explicitly states that it heavily judges the market position of the asset. Moody's, FMEA, and the Korean guidelines do not explicitly categorize this variable on their main assessment frameworks but do include its influence in their revenue analysis.

\section{Data analysis}

\subsection{Data description}

This study tests the practicality of the proposed rating model using the investment deals managed from 2016 to 2018 by an investment bank in South Korea. The limited

Table 4. LTV

\begin{tabular}{|c|c|c|c|c|c|c|c|c|c|}
\hline Scale & AAA & AA & A & BBB & BB & B & CCC & CC & C \\
\hline LTV & - & - & - & Less than $20 \%$ & $21 \sim 60 \%$ & $61 \sim 70 \%$ & $71 \sim 80 \%$ & $81 \sim 90 \%$ & $91 \sim 100 \%$ \\
\hline
\end{tabular}

Note: In the case of equity funding, C grade assigned.

Table 5. Rating adjustment

\begin{tabular}{|c|c|c|c|c|c|c|c|c|c|c|}
\hline \multirow{2}{*}{ Country } & The country rating & AAA & AA & A & $\mathrm{BBB}$ & $\mathrm{BB}$ & $\mathrm{B}$ & CCC & $\mathrm{CC}$ & $\mathrm{C}$ \\
\hline & Adjustment & 0 & 0 & 0 & 0 & -1 & -2 & -3 & -4 & -5 \\
\hline \multirow{2}{*}{ Location } & Asset's location & \multicolumn{4}{|c|}{ Urban area } & \multicolumn{5}{|c|}{ Rural area } \\
\hline & Adjustment & \multicolumn{4}{|c|}{+1} & \multicolumn{5}{|c|}{0} \\
\hline
\end{tabular}


data availability containing 37 transaction records in the three years cannot assure $100 \%$ the quality of the proposed work but can help building guidance for implementation: among 37 transactions, 4 transactions are executed in 2016, 8 transactions in 2017, and 25 transactions in 2018 (Table 7). Two factors mainly cause such data shortage. The first is a big scale with weak turnover rate. An underwriting size for a real asset in average is $\$ 50 \mathrm{M}$, and the period of resale of such position to an end-investor in average is 6 months. Second, it is a new trend that investment banks brokerage real asset deals. This trend just started a few of years ago, and the investment bank targeted by this study joined the new area in 2016 .

The data consist of five categories: Hotel, Industrial, Infrastructure, Office, and Residential. Each category is further subdivided into domestic and overseas (Table 6). In terms of profit rate, residential-domestic ranks highest $(9.0 \%)$, while the lowest is infrastructure (5.4\%). Residential-domestic projects having the highest profit rate can be explained by two factors: liquidity and greenfield. The residential-domestic category is exposed to a high market demand uncertainty, something principally attributed to an increase in risk and required return. In addition, the fact that these projects are in the construction phase and have high uncertainty in terms of building implementation and revenue generation incurs a risk premium. In spite of the high risk, 12 of 37 transactions (32.4\%) are also concentrated in this category. It means that developers believe that Korea's high population density and continuous economic development make the residential sector one of the most lucrative areas in terms of risk and return profile. In contrast, overseas residential projects have not been executed. The first reason for this is that most residential deals tend to be locally transacted due to their income stability and relatively better risk resilience against the economic cycle. Second, the heavy locality of the residential market causes information asymmetry. Diverse local variables, such as traffic, school district, crime rate, and other social variables that local residents accurately define, affect house price.
On the other hand, infrastructure deals having the lowest profit rate is acceptable, given that they are fully operational and have historical cash-flow records. Several overseas transactions were executed but domestic deals were not. This is due to weakened domestic supply and demand. On the supply side, the Korean government has increased its welfare budget in 2017 while cutting its Social Overhead Capital (SOC) expenditure. The decline delayed the implementation schedule for public infrastructure. On the demand side, the government's enforcement of controls on regulated return in favour of concessionaires negatively impacts the investment sentiment of financial institutions. Specifically, since abolishment of MRG, the popularity of the Korean PPP market has cooled down.

\subsection{Data analysis}

Table 7 consists of two sections: deal description and rating. The primary source of input is the Information Memorandum (IM), a proposal for deal transactions usually delivered by the seller to potential buyers. All information can be directly secured from the IM. The output is the result converted from the input.

In order to illustrate the rating process in detail, Cases $\# 13$, \#32, and \#33 are presented in detail. Case \#13 is a project to provide a mezzanine loan to a property owner of a hotel in the central business district of London, UK. The tenant is a world-class hotel chain, and the time remaining on the leasing term is over twice the loaning period. As this is a typical offtake contract, the credit risk of the tenant is a key determinant. The credit rating of the tenant is BBB, as measured by an international rating agency, and is presumed to be a grade of offtaker. The grade is the same assigned to Operation. The LTV of $62.5 \%$ where this mezzanine loan is located results in a B grade according to the table. The rating of each category is merged according to the weight standard, and $\mathrm{BB}$ is assigned as an interim project rating. In the rating adjustment step, the interim rating is upshifted one notch because the asset is located inside an urban area. The sovereign rating between Korea

Table 6. Investment deals

\begin{tabular}{|c|c|c|c|c|c|c|c|c|}
\hline \multirow{2}{*}{\multicolumn{2}{|c|}{ Category }} & \multirow{3}{*}{$\begin{array}{c}\text { Count } \\
1\end{array}$} & \multicolumn{3}{|c|}{ Profit rate $(\%)$} & \multicolumn{3}{|c|}{ LTV (\%) } \\
\hline & & & \multirow{2}{*}{$\frac{\text { Min }}{5.5}$} & \multirow{2}{*}{$\begin{array}{c}\text { Avg. } \\
5.5\end{array}$} & \multirow{2}{*}{$\frac{\operatorname{Max}}{5.5}$} & \multirow{2}{*}{$\frac{\text { Min }}{67}$} & \multirow{2}{*}{$\frac{\text { Avg. }}{67}$} & \multirow{2}{*}{$\frac{\operatorname{Max}}{67}$} \\
\hline Hotel & Domestic & & & & & & & \\
\hline & Overseas & 2 & 6.0 & 6.0 & 6.0 & 63 & 65 & 68 \\
\hline \multirow[t]{2}{*}{ Industrial } & Domestic & 5 & 7.5 & 8.7 & 9.7 & 50 & 58 & 67 \\
\hline & Overseas & 1 & 8.0 & 8.0 & 8.0 & 100 & 100 & 100 \\
\hline \multirow[t]{2}{*}{ Infra } & Domestic & 4 & 5.0 & 5.4 & 6.0 & 76 & 90 & 100 \\
\hline & Overseas & 9 & 5.8 & 8.6 & 12.5 & 16 & 57 & 100 \\
\hline \multirow[t]{2}{*}{ Office } & Domestic & 2 & 7.8 & 7.9 & 8.0 & 100 & 100 & 100 \\
\hline & Overseas & 12 & 4.1 & 9.0 & 11.8 & 27 & 58 & 100 \\
\hline \multirow[t]{2}{*}{ Residential } & Domestic & 1 & 5.6 & 5.6 & 5.6 & 48 & 48 & 48 \\
\hline & Overseas & 1 & 5.5 & 5.5 & 5.5 & 67 & 67 & 67 \\
\hline
\end{tabular}


Table 7. Credit rating

\begin{tabular}{|c|c|c|c|c|c|c|c|c|c|c|c|c|c|c|}
\hline \multirow[b]{2}{*}{ No } & \multicolumn{8}{|c|}{ Deal description } & \multicolumn{6}{|c|}{ Rating } \\
\hline & Year & Type & $\$ M$ & Country & Area & $\begin{array}{l}\text { Invest } \\
\text { type }\end{array}$ & $\begin{array}{l}\text { Profit } \\
(\%)\end{array}$ & $\begin{array}{l}\text { LTV } \\
(\%)\end{array}$ & $\begin{array}{c}\text { Off } \\
\text { taker }\end{array}$ & $\begin{array}{l}\text { Market } \\
\text { demand }\end{array}$ & LTV & $\begin{array}{l}\text { Oper. } \\
\text { or } \\
\text { const. }\end{array}$ & $\begin{array}{l}\text { Proj. } \\
\text { rate }\end{array}$ & $\begin{array}{l}\text { Final } \\
\text { rate }\end{array}$ \\
\hline 1 & 2016 & Off & 20 & Dom & Urban & Lend & 5.8 & 91.3 & - & BBB & $\mathrm{C}$ & BBB & $\mathrm{BB}$ & BBB \\
\hline 2 & 2016 & Off & 190 & Dom & Urban & Lend & 9.1 & 69.4 & - & B & B & $\mathrm{A}$ & $\mathrm{BB}$ & BBB \\
\hline 3 & 2016 & Res & 90 & Dom & Urban & Lend & 8.3 & 29 & - & BBB & $\mathrm{BB}$ & BBB & BBB & $\mathrm{A}$ \\
\hline 4 & 2016 & Res & 70 & Dom & Urban & Equity & 8.2 & 100 & - & BBB & $\mathrm{C}$ & BBB & $\mathrm{BB}$ & BBB \\
\hline 5 & 2017 & Ind & 50 & Dom & Rural & Lend & 9.5 & 50 & - & $\mathrm{BB}$ & $\mathrm{BB}$ & A & $\mathrm{BB}$ & $\mathrm{BB}$ \\
\hline 6 & 2017 & Off & 23 & Over & Urban & Equity & 7.8 & 100 & $\mathrm{AA}$ & - & $\mathrm{C}$ & $\mathrm{A}$ & BBB & A \\
\hline 7 & 2017 & Off & 80 & Dom & Urban & Lend & 8.0 & 42.2 & - & CCC & $\mathrm{BB}$ & BBB & B & $\mathrm{BB}$ \\
\hline 8 & 2017 & Off & 60 & Dom & Urban & Lend & 7.3 & 59.0 & - & BBB & $\mathrm{BB}$ & BBB & BBB & A \\
\hline 9 & 2017 & Off & 20 & Dom & Urban & Lend & 7 & 18.1 & - & CCC & BBB & $\mathrm{BB}$ & B & $\mathrm{BB}$ \\
\hline 10 & 2017 & Off & 36 & Dom & Urban & Lend & 12.5 & 15.8 & - & $\mathrm{BB}$ & BBB & BBB & BBB & A \\
\hline 11 & 2017 & Ind & 20 & Dom & Rural & Lend & 7.5 & 59.4 & - & $B$ & $\mathrm{BB}$ & BBB & $\mathrm{BB}$ & $\mathrm{BB}$ \\
\hline 12 & 2017 & Res & 30 & Dom & Urban & Equity & 11.8 & 70.6 & - & $\mathrm{BB}$ & CCC & BBB & $\mathrm{BB}$ & BBB \\
\hline 13 & 2018 & Hot & 45 & Over & Urban & Lend & 6.0 & 62.5 & BBB & - & B & BBB & $\mathrm{BB}$ & BBB \\
\hline 14 & 2018 & Res & 41 & Dom & Rural & Lend & 6.6 & 59.8 & - & $\mathrm{BB}$ & $\mathrm{BB}$ & BBB & $\mathrm{BB}$ & $\mathrm{BB}$ \\
\hline 15 & 2018 & Ind & 10 & Dom & Rural & Lend & 9.7 & 61.8 & - & $\mathrm{BB}$ & B & $\mathrm{BB}$ & $\mathrm{BB}$ & $\mathrm{BB}$ \\
\hline 16 & 2018 & Res & 30 & Dom & Rural & Lend & 8.0 & 39.3 & - & BBB & $\mathrm{BB}$ & BBB & BBB & BBB \\
\hline 17 & 2018 & Inf & 200 & Over & Rural & Lend & 5.4 & 75.6 & A & - & CCC & $\mathrm{BB}$ & BB & $\mathrm{BB}$ \\
\hline 18 & 2018 & Off & 7 & Dom & Urban & Lend & 5.9 & 68.5 & $\mathrm{BB}$ & - & B & $\mathrm{BB}$ & $\mathrm{BB}$ & BBB \\
\hline 19 & 2018 & Hot & 50 & Over & Urban & Lend & 6.0 & 68 & - & $\mathrm{BB}$ & B & A & $\mathrm{BB}$ & $\mathrm{BB}$ \\
\hline 20 & 2018 & Res & 15 & Dom & Rural & Lend & 11.8 & 53.7 & - & $\mathrm{BB}$ & $\mathrm{BB}$ & BBB & $\mathrm{BB}$ & $\mathrm{BB}$ \\
\hline 21 & 2018 & Res & 15 & Dom & Rural & Lend & 11.5 & 50.2 & - & BB & BB & $\mathrm{BB}$ & $\mathrm{BB}$ & $\mathrm{BB}$ \\
\hline 22 & 2018 & Res & 5 & Dom & Rural & Lend & 5.6 & 53.9 & - & $\mathrm{BB}$ & $\mathrm{BB}$ & $\mathrm{BB}$ & $\mathrm{BB}$ & $\mathrm{BB}$ \\
\hline 23 & 2018 & Off & 118 & Over & Urban & Equity & 8.0 & 100 & - & BBB & $\mathrm{C}$ & BBB & $\mathrm{BB}$ & $\mathrm{BB}$ \\
\hline 24 & 2018 & Off & 50 & Dom & Urban & Equity & 10.0 & 100 & - & B & $\mathrm{C}$ & BBB & B & $\mathrm{BB}$ \\
\hline 25 & 2018 & Res & 5 & Dom & Urban & Lend & 11.0 & 63.5 & - & $\mathrm{BB}$ & $B$ & $\mathrm{BB}$ & $\mathrm{BB}$ & BBB \\
\hline 26 & 2018 & Inf & 94 & Over & Rural & Equity & 6.0 & 100 & $\mathrm{AA}$ & - & $\mathrm{C}$ & BBB & BBB & BBB \\
\hline 27 & 2018 & Res & 3 & Dom & Urban & Lend & 4.1 & 26.8 & - & $\mathrm{BB}$ & $\mathrm{BB}$ & $\mathrm{BB}$ & $\mathrm{BB}$ & BBB \\
\hline 28 & 2018 & Inf & 150 & Over & Rural & Equity & 5.0 & 100 & $\mathrm{AA}$ & - & $\mathrm{C}$ & $\mathrm{BB}$ & $\mathrm{BB}$ & $\mathrm{BB}$ \\
\hline 29 & 2018 & Hot & 35 & Dom & Urban & Lend & 5.5 & 67 & $\mathrm{BB}$ & - & B & $\mathrm{BB}$ & $\mathrm{BB}$ & BBB \\
\hline 30 & 2018 & Ind & 24 & Dom & Rural & Lend & 9.2 & 66.9 & - & $\mathrm{A}$ & B & A & BBB & BBB \\
\hline 31 & 2018 & Off & 20 & Dom & Urban & Lend & 11.5 & 50.4 & - & $\mathrm{BB}$ & $\mathrm{BB}$ & BBB & $\mathrm{BB}$ & BBB \\
\hline 32 & 2018 & Inf & 183 & Over & Rural & Lend & 5.0 & 85 & A & - & CCC & $\mathrm{BB}$ & $\mathrm{BB}$ & $\mathrm{BB}$ \\
\hline 33 & 2018 & Res & 24 & Dom & Rural & Lend & 10.8 & 71.4 & - & $\mathrm{C}$ & B & $\mathrm{BB}$ & CCC & CCC \\
\hline 34 & 2018 & Ind & 26 & Over & Urban & Equity & 8.0 & 100 & - & $\mathrm{BB}$ & $\mathrm{C}$ & BBB & B & $\mathrm{BB}$ \\
\hline 35 & 2018 & Res & 10 & Dom & Rural & Equity & 10.0 & 78 & - & $\mathrm{CC}$ & CCC & BBB & CCC & CCC \\
\hline 36 & 2018 & Ind & 9 & Dom & Rural & Lend & 7.5 & 50 & - & $\mathrm{BBB}$ & $\mathrm{BB}$ & BBB & BBB & BBB \\
\hline 37 & 2018 & Ret & 20 & Dom & Rural & Lend & 5.6 & 48.3 & - & $\mathrm{BB}$ & $\mathrm{BB}$ & BBB & $\mathrm{BB}$ & $\mathrm{BB}$ \\
\hline
\end{tabular}

Note: Res: Residential. Off: Office, Ind: Industrial, Ret: Retail, Hot: Hotel, Inf: Infra, Dom: Domestic, Over: Overseas Operator (Oper.). Constructor (Const.).

and the UK is the same at AA; hence, there is no change. $A$ rating of $\mathrm{BBB}$ is finally derived.

Case \#32 is to provide acquisition financing to a UK energy company. The target asset is a renewable energy power plant located in a rural area in Spain, and it has been in operation since early 2000 . The principal revenue source is a government subsidy that compensates for capital and operation costs. Therefore, it is critical to assess the risks of public policy consistency and offtaker payment capacity. Spain's sovereign rating of $A$, is regarded as a grade of offtaker. The buyer's credit rating of $\mathrm{BB}$ is assigned to the operation grade, as the buyer will directly operate the asset. The elevated LTV rating of CCC is caused by a high LTV ratio of $85 \%$. The initial rating is determined $\mathrm{BB}$. In the adjustment step, no further calibration is required. Finally, a rating of $\mathrm{BB}$ is confirmed. 
Case \#33 is to provide mezzanine financing to a greenfield project of building private condominiums. The location is Jeju island, Korea, located $600 \mathrm{~km}$ from Seoul. The profit rate is outstanding, $10.8 \%$, but the deal was rejected by the investment board due to uncontrollable risks in market demand. Demand for this project should be projected based on local market performance. Since 2015, the housing market in Jeju has been strong, and housing supply has skyrocketed. Due to this oversupply, the occupancy rate in the region has dropped since 2018. Thus, the risk assessment team assigned a $\mathrm{C}$ grade to the market demand. The low market demand causes a low rating of CCC in the initial step. In the adjustment step, the rating is not changed due to the domestic project and rural location. Finally, CCC is confirmed.

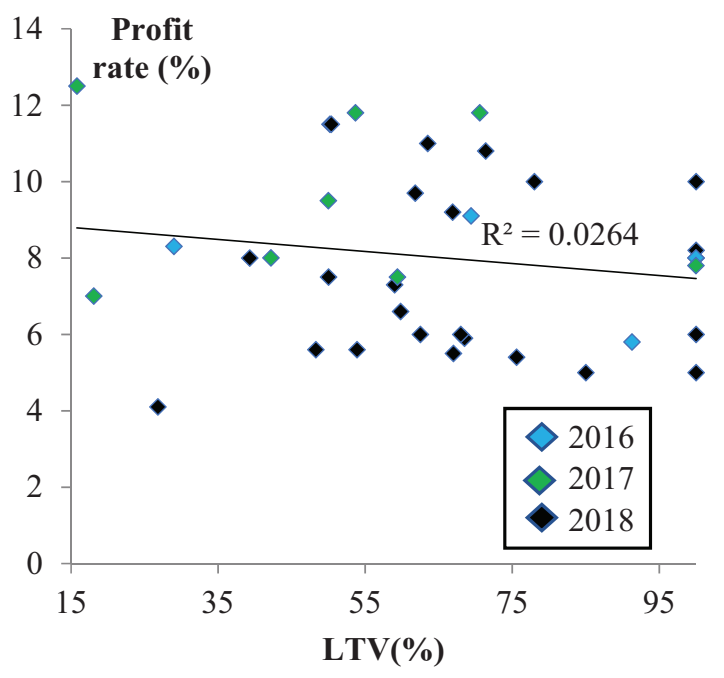

a) LTV vs Profit rate

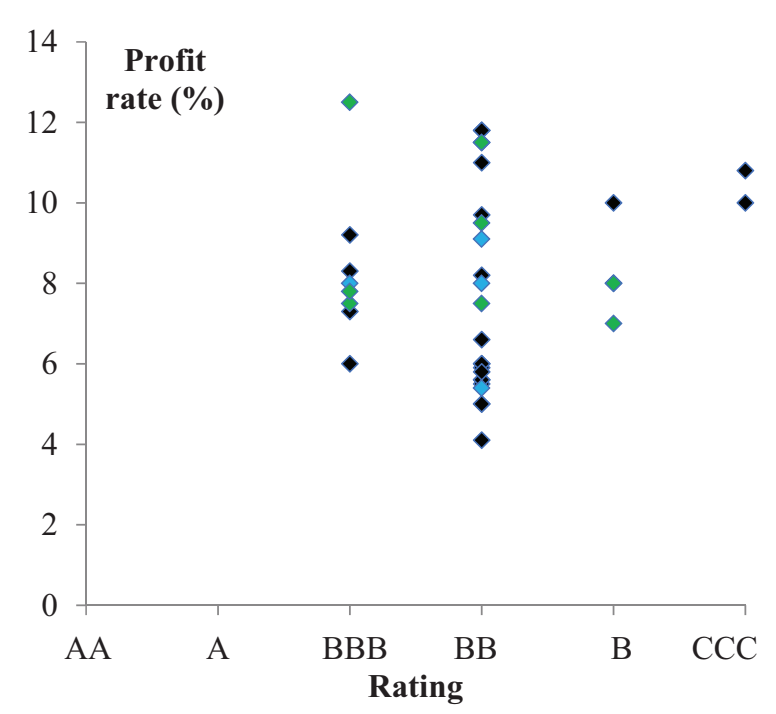

c) Preliminary rating vs Profit rate
Four analyses are compared in order to examine the practicality of the proposed model (Figure 4). High financial leverage weakens cash liquidity and impairs principal recovery at default. In other words, high leverage in general requires a high-risk premium, upsizing an expected profit rate. However, Figure 4a does not show a correlation between LTV and profit rate. The rationale is that other criteria can compensate for the drawback. In case \#20, the LTV of $85 \%$ results in a rating of CCC, but the ratings of the offtaker and operator, which are higher than the LTV, lead to the initial rating of BB. Such findings lead to the conclusion that LTV is not a standalone risk criterion.

Second, the relationship between investment amount and profit rate is reviewed (Figure $4 \mathrm{~b}$ ). This variable (R2: 0.080 ) is a better fit than LTV (R2: 0.026). Here, a higher

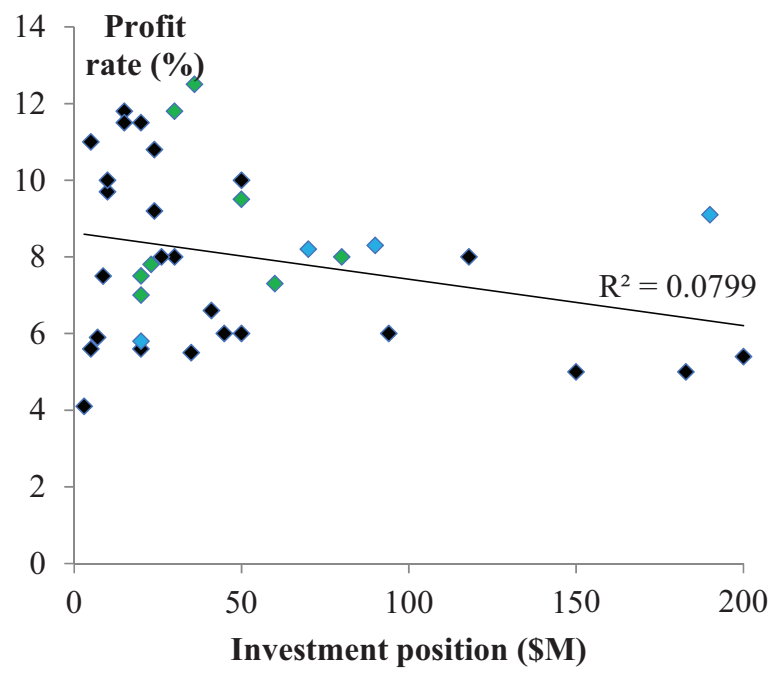

b) Investment amount vs Profit rate

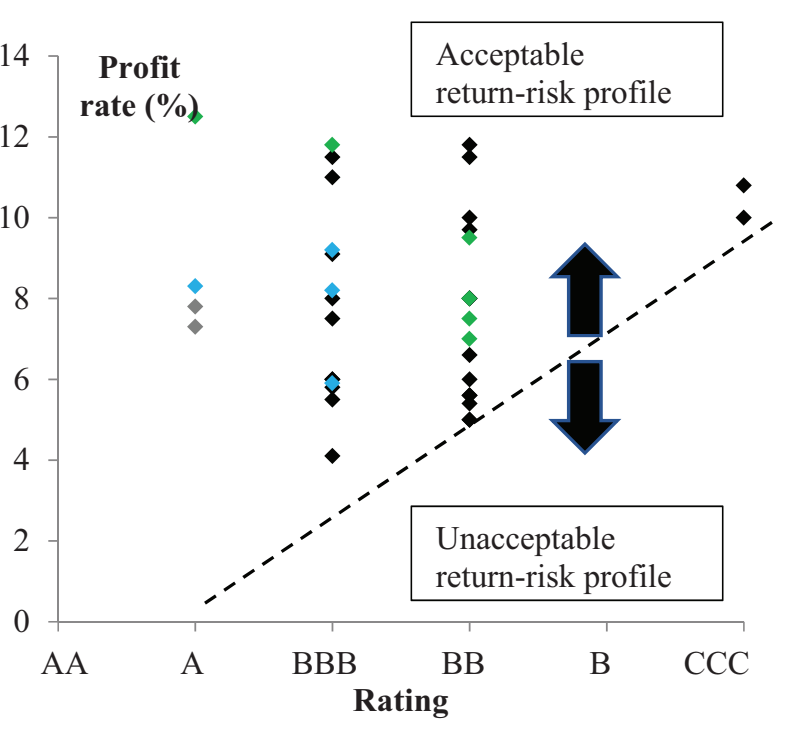

d) Final rating vs Profit rate 
investment amount leads to a smaller expected return rate. This finding is agreeable due to the empirical knowledge that financial institutions become more risk averse in proportion to the size of financing. However, the scale of investment cannot be objectively segmented to use as a risk indicator. Also, investment size can easily be resized without changes to deal configuration.

Third, the result of the initial rating, which is determined by the combined assessments of demand, operator, and LTV, is analysed (Figure 4c). In comparison to the cases mentioned above, this more clearly demonstrates the premise of high risk and high return. On the BB grade, a cluster can be observed, weakening the practicality of the proposed model. This finding strengthens the necessity of including more risk assessment criteria.

Forth, the outcome of the proposed model, with location and sovereign rating variables added to the previous model, shows more distinct relationships between risk and return (Figure 4d). A tendency of risk-return profile is observed. Specifically, the trend of the minimum profit level is more obvious than that of the maximum. This finding justifies the practicality of the proposed model. Standard \& Poor's (2018) states that in terms of both infrastructure project finance and corporate infrastructure, the BBB rating is achieved in most cases (42\%), a finding sustained since 2000. In terms of real estate, Standard \& Poor's (2016) reports that the median rating is BBB-. Such derived risk-return borderline provides an insight in regards to setting an admissible threshold.

\section{Discussion}

Determining the level of risk appetite for real asset products is challenging for financial institutions. This is in contrast to conventional products such as stocks and bonds, in which market price and risk premiums can be objectively identified. The idiosyncratic features of each transaction in the real asset market require decision makers to define acceptable risk thresholds based on their empirical experiences, or in other words, their subjectivity. The proposed model aims to develop a fast screening rating system. However, although the rating outcome generated by the model is agreeable, it may encounter several counter arguments in terms of its practicality.

First, insufficient data potentially lead to the study's outcome deviating from practice. Its result shows that a rating is ideally correlated with its profit rate, illustrating a tendency for high risk and high return. However, the data used in this study have 37 cases, and the period is three years from 2016 to 2018. Due to the lack of data, this study analyzes rating results regardless of their types. If ratings are compared in the same group, the practicality can be better justified. In addition, the study uses data of three years period. An expected return is determined by adding a risk premium, which is inherited from the asset's uniqueness, to a benchmark interest rate with the same maturity, which is determined in the market. As a quantitative description of a rating is a risk premium, comparing ratings and risk premiums (profit rate - benchmark interest rate) in more than 10 years' records can strengthen the model.

Second, the rating results cannot fully avoid subjectivity issues. The main input sources of this rating platform in regards to offtaker and operator and constructor are credit ratings confirmed by a global credit rating agency. This third-party rating is in general regarded as trustworthy, but occasionally fails to accurately describe the object's status. AAA grade companies, such as Lehman Brothers, AIG, etc., were dismantled during the financial crisis. The main cause of such failures is subjectivity in decision making. Unfortunately, no alternative has yet been developed in order to replace the credit rating system. Outside periods of economic turmoil, rating information is regarded as reliable in the financial market. In addition, it is hard for financial institutions to collect and analyze large amounts of data and assign a grade. These circumstances justify this model's approach of using rating information as a main source.

Third, the result can be misguided by the instant and incomprehensive rating system utilized in this study. Global rating agencies deliver a rating by employing a full-scale review system in which experienced raters and sophisticated systems assess all dimensional risks, from underlying asset performance to macro environment status. The criticality in determining rating quality is inherited from the consistency and accuracy of the rating conductor's responses and the standardized rating scale and system. These rating agencies have invested huge capital to meet such challenges. However, financial institutions that seek to punctually assess the risks of real assets cannot employ a complex system due to budget and time constraints. As an alternative, the proposed model, which analyzes key aspects of a deal structure without requiring trained personnel and extensive time, may correspond to the banker's need. The feature of the core risks being extracted from BIS's regulations and assessments executed by third-party sources, excluding subjective decisions, strengthens the reliability of the model.

\section{Conclusions}

Capital flow to alternative investment has expanded since the 2008 financial crisis to avoid the return volatility usually observed in the traditional market and to secure portfolio diversity. Real asset investments, such as real estate and infrastructure, are core groups of alternative investment. Their key advantage is to secure stability in project returns during the holding. However, challenges caused by a lack of liquidity and great information asymmetry raise the bar for participation. Heterogeneous features of each transaction's profile also make it ineffective to introduce a benchmark return index, which also hinders investors' access to this market.

The newly developed rating method suggested by this study has been invented to address such issues. Simply designed but utilizing core risk criteria, it contributes to reducing information asymmetry and building investment benchmarks. Like other conventional and theoretical 
models, this assesses various risk dimensions under a concretely standardized architecture and results in a rating that can be interpreted to a grade delivered by a commercial agency. Such comparability is assured by the background of the proposed system that is developed in inheriting the scheme of Moody's.

However, the shortcoming aroused by the simplification can overwhelm the proposed model's positive features. The exclusion increases the chance of overlooking critical features that the current qualitative and in-depth analysis models identify. Future research will overcome such issues by employing more varied sources and techniques.

\section{References}

Allison, R., \& Tufts, S. (2015). Infrastructure investments: an attractive option to help deliver a prosperous and sustainable economy. Retrieved from https://www.ey.com/Publication/ vwLUAssets/EY-infrastructure-investments/\$FILE/EY-infrastructure-investments.pdf

Bae, D. S., \& Damnjanovic, I. (2018). Credit risk assessment and monitoring of TIF bonds. The Journal of Structured Finance, 23(4), 57-68. https://doi.org/10.3905/jsf.2018.2018.1.062

Bank for International Settlements. (2001). Working paper on the internal ratings-based approach to specialised lending exposures. Retrieved from https://www.bis.org/publ/bcbs_wp9.pdf

Bank for International Settlements. (2017). High-level summary of Basel III reforms. Retrieved from https://www.bis.org/bcbs/ publ/d424_hlsummary.pdf

Bank of England. (2019). Internal Ratings Based (IRB) approaches. Retrieved from https://www.bankofengland.co.uk/ prudential-regulation/publication/2013/internal-ratingsbased-approaches-ss

Barkham, R., \& Luo, W. (2018). Global investment volume rises, driven by robust U.S. market. Retrieved from https://www. cbre.com/research-and-reports/global-marketflash-globalinvestment-volume-rises

Bonsall, S., Koharki, K., \& Neamitu, M. (2015). The effectiveness of credit rating agency monitoring: evidence from asset securitization. The Accounting Review, 90(5), 1779-1810. https://doi.org/10.2308/accr-51028

Bonsall, S. B., Koharki, K., \& Neamtiu, M. (2017). When do differences in credit rating methodologies matter? Evidence from high information uncertainty borrowers. The Accounting Review, 92(4), 53-79. https://doi.org/10.2308/accr-51641

CBRE. (2017). The global market leader in commercial real estate services. Retrieved from http://phx.corporate-ir.net/External. File?item=UGFyZW50SUQ9Njc5MzI4fENoaWxkSUQ9Mzg 4NDM4fFR5cGU9MQ==\&t=1

Choi, S. C. (2018). Expedited infrastructure investment by asset management company. Business Post Korea. Retrieved from http://www.businesspost.co.kr/BP? command=article_ view\&num $=88116$

Fracassi, C., Petry, S., \& Tate, G. (2013). Are credit ratings subjective? The role of credit analysts in determining ratings. Retrieved from https://www.aeaweb.org/conference/2014/retrieve.php?pdfid=551

Garmaise, M. J., \& Moskowitz, T. J. (2003). Confronting information asymmetries: evidence from real estate markets. The Review of Financial Studies, 17(2), 405-437. https://doi.org/10.1093/rfs/hhg037
Griffin, J. M., \& Tang, D. Y. (2012). Did subjectivity play a role in CDO credit ratings? The Journal of Finance, 67(4), 1293-1328. https://doi.org/10.1111/j.1540-6261.2012.01748.x

He, Y., Wang, J., \& Wei, K. C. J. (2011). Do bond rating changes affect the information asymmetry of stock trading? Journal of Empirical Finance, 18(1), 103-116. https://doi.org/10.1016/j.jempfin.2010.06.001

Heitmann, K., \& Davison, A. (2018). Moody's: default and recovery rates for project finance bank loans remain stable. Retrieved from https://www.moodys.com/research/Moodys-Default-andrecovery-rates-for-project-finance-bank-loans--PR_380331

Heitmann, K., Hawken, N., \& Davison, A. (2017). Default and recovery rates for project finance bank loans, 1983-2015. Retrieved from https://www.globalinfrafacility.org/sites/gif/files/ Moody\%27s-Project\%20Finance\%20Default\%20Study\%20 \%281983-2015\%29.pdf

Hull, J. C., Predescu, M., \& White, A. (2005). Bond prices, default probabilities and risk premiums. SSRN. https://doi.org/10.2139/ssrn.2173148

Korean Ministry of Land Infrastructure and Transport. (2016). Overseas infrastructure development support policy. Retrieved from http://www.molit.go.kr/USR/I0204/m_45/ dtl.jsp?gubun=1\&search=\&search_dept_id=\&search_

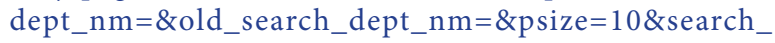
regdate_s=\&search_regdate_e $=\& s r c h \_u s r \_n m=\& s r c h$ usr_num $=\& s r c h \_u s r \_y e a r=\& s r c h \_u s r \_t i t l=\& s r c h \_u s r \_$ ctnt $=\& 1 \mathrm{cmspage}=1$ \&id $\mathrm{x}=14391$

KPMG. (2019). Emerging trends in infrastructure 2019. Retrieved from https://home.kpmg/xx/en/home/industries/infrastructure.html

Longstaff, F. A., Mithal, S., \& Eric, N. (2005). Corporate Yield spreads: default risk or liquidity? New evidnece from the credit default swap market. The Journal of Finance, 60(5), 2213-2253. https://doi.org/10.1111/j.1540-6261.2005.00797.x

M\&G Institutional. (2017). The opportunity in European commercial real estate debt. Retrieved from http://www.mandg. $\mathrm{hk} /$ institutional/articles/the-opportunity-in-european-commercial-real-estate-debt/-/media/68C366BD7CE0436B94AA 36482F885AAD.pdf

McKinsey \& Company. (2017). Basel "IV": what's next for banks? Retrieved from https://www.mckinsey.com/ /media/mckinsey/business\%20functions/risk/our\%20insights/basel\%20 iv\%20whats\%20next\%20for\%20european\%20banks/basel-ivwhats-next-for-banks.ashx

Medina, J. (2018). Moody's update its methodology for rating generic project finance issuers. Retrieved from https://www. moodys.com/research/Moodys-updates-its-methodology-forrating-generic-project-finance-issuers--PR_382107

Medina, J., \& Marty, D. (2018). Rating methodology: generic project finance. Retrieved from https://www.moodys.com/researchdocumentcontentpage.aspx?docid=PBC_1091596

Meers, W., \& Humphrey, T. (2017). Macquarie infrastructure debt investment solutions: an introduction to infrastructure debt. Retrieved from https://www.macquarie.com/dafiles/ Internet/mgl/global/shared/sf/pdf/midis-an-introduction-toinfrastructure-debt.pdf? $\mathrm{v}=2$

Morgan Stanley. (2014). Alternative investments: innovative strategies for asset allocation. Retrieved from https://www.morganstanley.com/wealth/investmentsolutions/pdfs/altscapabilitiesbrochure.pdf

Morgenson, G. (2009). When bond ratings get stale. Retrieved from https://www.nytimes.com/2009/10/11/business/ economy/11gret.html 
Moultrie, J. (2019). FMEA (Failure Modes and Effects Analysis). Retrieved from https://www.ifm.eng.cam.ac.uk/research/ $\mathrm{dmg} /$ tools-and-techniques/fmea-failure-modes-and-effectsanalysis/

Nikolića, D. M., Jednak, S., Benković, S., \& Poznanić, V. (2011). Project finance risk evaluation of the Electric power industry of Serbia. Energy Policy, 39(10), 6168-6177.

https://doi.org/10.1016/j.enpol.2011.07.017

Peng, J., \& Brucato, P. F. (2004). An empirical analysis of market and institutional mechanisms for alleviating information asymmetry in the municipal bond market. Journal of Economics and Finance, 28(2), 226-238. https://doi.org/10.1007/BF02761613

Piney, C. (2003). Risk identification: combining the tools to deliver the goods. Paper presented at the $\mathrm{PMI}^{\star}$ Global Congress 2003-EMEA, The Hague, South Holland, The Netherlands.

Raz, T., Shenhar, A. J., \& Dvir, D. (2002). Risk management, project success, and technological uncertainty. $R \& D$ Management, 32(2), 101-109. https://doi.org/10.1111/1467-9310.00243

Renigier-Biłozor, M., Wisniewski, R., Kaklauskas, A., \& Biłozor, A. (2014). Rating methodology for real estate markets - Poland case study. International Journal of Strategic Property Management, 18(2), 198-212. https://doi.org/10.3846/1648715X.2014.927401

Ribeiro, M. I. F., \& Ferreira, F. A. F. (2017). A fuzzy knowledgebased framework for risk assessment of residential real estate investments. Technological and Economic Development of Economy, 23(1), 140-156. https://doi.org/10.3846/20294913.2016.1212742
S\&P Global Ratings. (2018). S\&P Global Ratings definitions. Retrieved from https://www.standardandpoors.com/en_US/ web/guest/article/-/view/sourceId/504352

Segismundo, A., \& Miguel, P. A. C. (2008). Failure mode and effects analysis (FMEA) in the context of risk management in new product development: a case study in an automotive company. International Journal of Quality \& Reliability Management, 25(9), 899-912.

https://doi.org/10.1108/02656710810908061

Standard \& Poor's. (2014). Project finance ratings criteria reference guide. Retrieved from https://www.spratings.com/documents/20184/86990/SPRS_Project\%2BFinance\%2BRatings\% 2BCriteria\%2BReference\%2BGuide_FINAL/cdfde690-57d14ff4-a87f-986527603c22

Tang, T. T. (2009). Information asymmetry and firm's credit market access: evidence from moody's credit rating format refinement. Journal of Financial Economics, 93(2), 325-351. https://doi.org/10.1016/j.jineco.2008.07.007

The European Group of Valuer's Associations. (2003). European Property and Market Rating: A Valuer's Guide. Retrieved from https://www.tegova.org/data/bin/a56efb621c7ae1_EPMR1.pdf

United Nations Economic Commission for Europe Real Estate Market Advisory Group. (2012). Evaluation of real estate property and market risk for real estate backed financial products. Retrieved from https://www.unece.org/fileadmin/DAM/ $\mathrm{hlm} /$ sessions/docs2012/real_estate_property_and_market_ risk.pdf

Yescombe, E. R. (2002). Principles of project finance. Elsevier. https://doi.org/10.1016/B978-012770851-5.50002-6 